\title{
Expression of the tetraspanins CD9, CD37, CD63, and CD151 in Merkel cell carcinoma: strong evidence for a posttranscriptional fine-tuning of CD9 gene expression
}

Markus Woegerbauer ${ }^{1}$, Dietmar Thurnher ${ }^{1}$, Roland Houben ${ }^{2}$, Johannes Pammer ${ }^{3}$, Philipp Kloimstein ${ }^{1}$, Gregor Heiduschka ${ }^{1}$, Peter Petzelbauer ${ }^{4}$ and Boban M Erovic ${ }^{1}$

${ }^{1}$ Department of Otorhinolaryngology, Head and Neck Surgery, Medical University of Vienna, Vienna, Austria; ${ }^{2}$ Department of Dermatology, Medical University of Wuerzburg, Germany; ${ }^{3}$ Department of Clinical Pathology, Medical University of Vienna, Vienna, Austria and ${ }^{4}$ Department of Dermatology, Medical University of Vienna, Vienna, Austria

Tetraspanins including CD9, CD37, CD63, and CD151 are linked to cellular adhesion, cell differentiation, migration, carcinogenesis, and tumor progression. The aim of the study was to detect, quantify, and evaluate the prognostic value of these tetraspanins in Merkel cell carcinoma and to study the regulation of CD9 mRNA expression in Merkel cell carcinoma cell lines in detail. Immunohistochemical staining of 28 Merkel cell carcinoma specimens from 25 patients showed a significant correlation of CD9 $(P=0.03)$ and $C D 151(P=0.043)$ expression to overall survival. CD9 and CD63 expression correlated significantly to patients' disease-free interval $(P=0.017$ and $P=0.058)$. Of primary Merkel cell carcinoma tumors, $42 \%$ were CD9 positive in contrast to only $21 \%$ of the subcutaneous in-transit metastases. Characterization of the $5^{\prime}$ untranslated region (UTR) of the CD9 mRNA from two cultured Merkel cell carcinoma cell lines revealed the presence of two major RNA species differing only in the length of their $5^{\prime}$ termini (183 versus 102 nucleotides). In silico analysis of the long CD9 mRNA predicted a $5^{\prime}$ UTR folding pattern blocking ribosomal scanning and translation. Quantitative data by real-time RT-PCR not only indicated a reduction of CD9 mRNA but also a distinct quantitative shift toward the long $5^{\prime}$ UTR in CD9 receptor negative cells. These observations provide an example for a posttranscriptional fine-tuning of CD9 gene expression in tumor cells.

Modern Pathology (2010) 23, 751-762; doi:10.1038/modpathol.2009.192; published online 29 January 2010

Keywords: Merkel cell carcinoma; tetraspanins; regulation of gene expression

Merkel cell carcinoma is a highly aggressive neuroendocrine cancer of the skin predominantly occurring in elderly people. ${ }^{1,2}$ Treatment options and the 5-year overall survival rate of $33-40 \%$ are far from satisfactory. ${ }^{2-4}$ The availability of diagnostic tools to assess the aggressive potential of Merkel cell carcinoma and to allow an adequate patient-tailored therapy would be highly appreciated. ${ }^{5}$

Correspondence: Dr BM Erovic, MD, Department of Otorhinolaryngology, Head and Neck Surgery, Medical University of Vienna, Währinger Gürtel 18-20, Wien 1090, Vienna, Austria.

E-mail: boban.erovic@meduniwien.ac.at

Received 7 August 2009; revised 25 November 2009; accepted 7

December 2009; published online 29 January 2010
We evaluated the tetraspanins CD9, CD37, CD63, and CD151 for their applicability as prognostic factors in Merkel cell carcinoma. These proteins have been reported to be of prognostic value in different solid malignant tumors. ${ }^{6-8}$

Tetraspanins are transmembrane adaptor proteins, which are stabilizing or modulating the activity of partner molecules in membrane microdomains, and are involved in cell adhesion, motility, activation, proliferation, carcinogenesis, and tumor progression. ${ }^{9,10}$

CD151 is expressed intracellularly in a broad range of tissues (eg, epithelial and endothelial cells, platelets, megakaryocytes, monocytes). ${ }^{9}$ A high CD151 expression is closely correlated with tumor progression due to promotion of cell migrations by 
regulating integrin trafficking and, therefore, is indicative for a poor prognosis, eg in non-small cell lung cancer. ${ }^{8}$

CD63 shows also a broad tissue distribution and is predominantly localized in cytoplasmic lysosomes. ${ }^{10-12}$ It is strongly expressed in early melanoma and downregulated in later stages and, thus, a good prognosis factor for this malignancy. ${ }^{10,13}$

CD37 is only expressed to a substantial extent in MHC class II-enriched compartments of B cells and usually regulates the IgA response. ${ }^{10,14}$ It is a reliable marker for malignancies derived from mature B cells. ${ }^{15}$

CD9 is expressed in numerous tissues and has a pivotal role in cell adhesion, motility, and eggsperm fusion. ${ }^{10,16}$ It usually suppresses tumor progression and metastasis by inhibition of tumor proliferation and survival. ${ }^{9}$ Owing to its multitude of different functions in various tissues, the regulation of CD9 gene expression is of particular interest. ${ }^{10}$ Therefore, we decided to analyze CD9 mRNA expression in Merkel cell carcinoma cell lines in detail. The genome structure of CD9 revealed the presence of a GC-rich promoter preceding the CD9 coding region. ${ }^{17}$ In contrast to a conventional TATAand CAAT-box-containing promoter, which rather fixes the transcription start site, GC-rich promoters are prone for multiple mRNA initiation sites, leading to a population of mRNA species with different $5^{\prime}$ termini. ${ }^{18,19}$ Efficient mRNA translation is-besides several other constraints-substantially dependent on a supportive RNA folding pattern of the $5^{\prime}$ untranslated region (UTR) usually preceding eukaryotic mRNA translation initiation codons. ${ }^{20}$ Long $5^{\prime}$ UTRs with complex and stable RNA secondary structures and short open-reading frames-which is the case with CD9 mRNA-inhibit ribosomal scanning and translation. ${ }^{17,21}$

The aim of this study was to establish the expression patterns of the tetraspanins CD9, CD37, CD63, and CD151 in Merkel cell carcinoma tissue samples and to study the regulation of CD9 mRNA expression in Merkel cell carcinoma cell lines in detail. We provide evidence that the expression of these tetraspanins is of prognostic relevance concerning survival time and disease-free interval and supplies information about the metastatic potential of Merkel cell carcinoma tumors. Analysis of CD9 gene expression in Merkel cell carcinoma cell lines provides insights in how cells may fine-tune CD9 protein expression with high fidelity.

\section{Materials and methods}

All reagents were of molecular biology grade provided by Sigma-Aldrich (St Louis, MO, USA), unless otherwise stated. Reaction tubes (1.5 and $2 \mathrm{ml}$; Biopur) were from Eppendorf (Hamburg, Germany). All other consumables were from Sarstedt (Nümbrecht, Germany).

\section{Patients}

Samples of patients with Merkel cell carcinoma were collected from the Departments of Otorhinolaryngology, Head and Neck Surgery and Dermatology of the Medical University of Vienna. All patients were treated during the years 1991 and 2005. The clinical data are summarized in Table 1. All samples were staged according to the most commonly used system (stage I, local disease; stage II, loco regional disease; stage III, distant disease). ${ }^{22}$

\section{Tissue Specimens}

Twenty-eight Merkel cell carcinoma tissue samples from 25 patients were included in the study. Of these specimens, 13 were primary tumors and 15 were metastases. In particular, of these 15 specimens, 7 biopsies were subcutaneous in-transit metastases, 7 metastatic lymph nodes, and 1 recurrent primary tumor (Table 1). All tissue samples from our department and the Department of Dermatology suspected for Merkel cell carcinoma are routinely sent to the Department of Pathology, where diagnosis of all Merkel cell carcinomas has been verified by CK20 staining before the specimens were included in our study. CK20 staining of Merkel cell carcinoma tissue samples is routinely requested and performed at the Department of Pathology. Thus, all charts have been thoroughly checked before the start of our study.

\section{Tissue Microarray}

Hematoxylin-eosin-stained tissue sections $(2-3 \mu \mathrm{m})$ from each sample were evaluated for suitability before enrollment into the study. The following inclusion criteria were applied: size $(1-2 \mathrm{~mm}$ in depth and at least $5 \mathrm{~mm}$ in length and width), appropriate fixation, absence of significant electrosurgical device lesions, signs of acidic decalcifying agents, and the presence of usable tissue in each block. Each hematoxylin-eosin-stained slide was revaluated by our pathologists (PP, JP) and mapped to identify the specific areas for tissue acquisition to build the tissue microarrays. These arrays were constructed with a Beecher manual tissue arrayer (MTA-1; Beecher Instruments, WI, USA) according to Kononen et $a l^{23}$. The diameter of the core was $0.6 \mathrm{~mm}$. Three cores were used per patient.

\section{Immunohistochemistry}

Dewaxed and rehydrated tissue microarrays were subjected to antigen retrieval in a microwave oven $(600 \mathrm{~W})$ using the appropriate buffer (Table 2). Blocking of unspecific binding was achieved with $5 \%$ TBS/BSA (Sigma-Aldrich, Germany) for $1 \mathrm{~h}$ at room temperature. Application of the primary antibody (Table 2) and appropriate negative and positive 
Table 1 Clinical data of 25 patients with Merkel cell carcinoma

\begin{tabular}{|c|c|c|c|c|c|c|c|c|c|c|c|}
\hline$S / P^{a}$ & Type & Type of mets & Site & Stage & First treatment & Recurrence (months) & Second treatment & Third treatment & Status & $\begin{array}{c}T L F^{\mathrm{c}} \\
\text { (months) }\end{array}$ & $I S^{\mathrm{d}}$ \\
\hline $1 / 1$ & Primary & & Ear & I & Surgery & Local (4) & Surgery & & AW & 41 & $\mathrm{n}$ \\
\hline $2 / 2$ & Primary & & Nose & I & Surgery & NA & NA & NA & AW & 68 & $\mathrm{n}$ \\
\hline $3 / 3$ & Primary & & Hand & I & $\begin{array}{l}\text { Surgery + axillar } \\
\text { adenectomy }\end{array}$ & NA & NA & NA & DOC & 7 & $\mathrm{y}$ \\
\hline $4 / 4$ & Metastasis & LN & Foot & III & Surgery & Local (4)/metastasis (7) & Chemotherapy ${ }^{\mathrm{e}}$ & Chemotherapy ${ }^{\mathrm{f}}$ & DOD & 24 & $\mathrm{y}$ \\
\hline $5 / 5$ & Primary & & Thigh & I & Surgery & Regional (4) & RT (30/3) & NA & DOC & 36 & $\mathrm{n}$ \\
\hline $6 / 6$ & Primary & & Nose & I & Surgery & Local (11)/regional (12) & RT (60/2.5) & NA & DOD & 49 & $\mathrm{n}$ \\
\hline $7 / 7$ & Metastasis & Recurrent tumor & Cheek & I & Surgery & Local (6)/metastasis (11) & $\begin{array}{l}\text { Surgery + RT } \\
\text { (Betatron) }\end{array}$ & Endoxan ${ }^{\mathrm{g}}$ & DOD & 18 & $\mathrm{n}$ \\
\hline $8 / 8$ & Metastasis & LN & Neck & I & Surgery & Metastasis (5) & Surgery & NA & AW & 109 & $\mathrm{n}$ \\
\hline $9 / 9$ & Metastasis & In-transit & Cheek & II & $\begin{array}{l}\text { Surgery }+ \\
\text { adenectomy }\end{array}$ & Regional (6) & RT $(60 / 2)$ & NA & DOD & 24 & $\mathrm{y}$ \\
\hline $10 / 10$ & Metastasis & In-transit & Leg & I & Surgery & Regional (7) & Surgery & Surgery+RT (38/2) & AWD & 60 & $\mathrm{n}$ \\
\hline $11 / 11$ & Metastasis & In-transit & Elbow & I & Surgery & Regional (14)/metastasis (21) & Chemotherapy & RT (50/2) & AW & 30 & $\mathrm{y}$ \\
\hline $12 / 11$ & Metastasis & In-transit & NA & & Surgery & Regional (14)/metastasis (21) & Chemotherapy ${ }^{\mathrm{h}}$ & RT (50/2) & AW & 30 & $\mathrm{y}$ \\
\hline $13 / 12$ & Primary & & NA & I & Surgery & $\mathrm{NA}$ & NA & NA & AW & 34 & $\mathrm{n}$ \\
\hline $14 / 13$ & Primary & & Cheek & I & Surgery + RT (30) & NA & NA & NA & DOC & 18 & $\mathrm{y}$ \\
\hline $15 / 14$ & Primary & & Cheek & I & Surgery & NA & NA & NA & AW & 94 & $\mathrm{n}$ \\
\hline $16 / 15$ & Metastasis & In-transit & NA & & Surgery & Local (5)/metastasis (15) & Surgery+RT (65/2) & Surgery+RT (25/2) & DOC & 17 & $\mathrm{y}$ \\
\hline $17 / 15$ & Primary & & Neck & I & Surgery & Local (5)/metastasis (15) & Surgery+RT (65/2) & Surgery+RT (25/2) & DOC & 17 & $\mathrm{y}$ \\
\hline $18 / 16$ & Primary & & Forehead & II & Surgery & Local (4) & Surgery & NA & DOC & 82 & $\mathrm{n}$ \\
\hline $19 / 17$ & Metastasis & In-transit & Leg & III & $\begin{array}{l}\text { Surgery + inguinal } \\
\text { adenectomy + RT } \\
(30 / 2.5)\end{array}$ & NA & NA & NA & DOD & NA & NA \\
\hline $20 / 18$ & Primary & & Ear & I & Surgery & Metastasis (6) & Surgery + RT & NA & DOD & 6 & $\mathrm{y}$ \\
\hline $21 / 19$ & Primary & & Neck & I & Surgery & NA & $\mathrm{NA}$ & NA & DOC & 17 & $\mathrm{n}$ \\
\hline $22 / 20$ & Metastasis & LN & Head & I & Surgery & Regional (23) & Surgery & NA & DOD & 24 & $\mathrm{n}$ \\
\hline $23 / 21$ & Metastasis & LN & NA & & $\begin{array}{l}\text { Surgery + RT } \\
(30 / 2.5)\end{array}$ & Regional (37)/Metastasis (53) & Surgery & RT (50/2) & DOD & 58 & $\mathrm{n}$ \\
\hline $24 / 21$ & Metastasis & $\mathrm{LN}$ & Lid & I & $\begin{array}{l}\text { Surgery + RT } \\
(30 / 2.5)\end{array}$ & Regional (37)/metastasis (53) & Surgery & RT (50/2) & DOD & 58 & $\mathrm{n}$ \\
\hline $25 / 22$ & Metastasis & LN & Lid & I & Surgery & Regional (14) & Surgery & NA & AW & 44 & $\mathrm{n}$ \\
\hline $26 / 23$ & Metastasis & LN & Thigh & I & Surgery & Regional (3) & Surgery + RT (56/2) & Chemotherapy ${ }^{i}$ & DOD & 50 & $\mathrm{n}$ \\
\hline $27 / 24$ & Metastasis & In-transit & Arm & I & Surgery & Regional (2)/metastasis (12) & Surgery & RT (50/2) & DOD & 24 & $\mathrm{n}$ \\
\hline $28 / 25$ & Primary & & Forehead & II & Surgery + RT (50) & Regional (2)/metastasis (3) & RT (30/2.5) & NA & DOD & 6 & $\mathrm{n}$ \\
\hline
\end{tabular}

NA, no data available; RT, radiotherapy; AW, alive without disease; AWD, alive with disease; DOC, death of other causes; DOD, death of disease; LN, lymph node metastases.

${ }^{\mathrm{a}}$ Specimen no./patient no.

bype of metastases.

${ }^{\mathrm{c}}$ Time to last follow-up.

dimmunosuppression: $\mathrm{n}=$ no; $\mathrm{y}=$ yes.

${ }^{\mathrm{e}}$ Cisplatin, etoposide.

离 $\quad{ }^{\mathrm{f}}$ Adriamycine, cyclophosphamide, vincristine.

g Cyclophosphamide.

${ }^{\mathrm{h}}$ Cyclophosphamide, methotrexate, $5^{\prime}$-fluorouracil.

${ }^{\mathrm{i}}$ Doxorubicin, dacarbacin, ifosfamide. 
Table 2 Antibodies and retrieval buffers for each antibody

\begin{tabular}{llllr}
\hline Antibody & Supplier & Code & FC specificity & Dilution \\
\hline CD9 & Fitzgerald & RDI-MCD9-CB 01421 & Mouse & $1: 200$ \\
CD37 & Leica-Novocastra & NCL-CD37 138804 & EDTA \\
CD63 & Leica-Novocastra & NCL-CD63 142205 & Mouse & Citrate \\
CD151 & Leica-Novocastra & NCL-CD151 153404 & Mouse & $1: 500$ \\
& & & Citrate \\
\hline
\end{tabular}

${ }^{\mathrm{a}} 1 \mathrm{mM}$ EDTA, pH 8.

$\mathrm{b}_{0.01 \mathrm{M} \text { citrate buffer, } \mathrm{pH} 6 .}$

control was carried out at $4{ }^{\circ} \mathrm{C}$ overnight. A secondary biotinylated antibody (1:200 resuspended in 1\% TBS/BSA, Multilink; Dako, DK) was used for $1 \mathrm{~h}$ at room temperature, followed by a $1 \mathrm{~h}$ incubation with alkaline phosphatase conjugated to streptavidin in 1\% TBS/BSA (1:250; Dako, DK) at room temperature. Visualization was performed by Fast Red (Sigma-Aldrich) and counterstained by hemalaun. Samples were analyzed using an Olympus BH-2 microscope.

\section{Specimen Classification Based on Immunohistochemical Results and Morphological Features}

The immunoreactivity score proposed by Sinicrope et $a l^{24}$ to evaluate both the intensity of immunohistochemical staining and the proportion of the stained tumor cells was applied. The staining intensity was subclassified as follows: 1 , weak; 2 , moderate; or 3 , strong. The positive cells were quantified as a percentage of the total number of tumor cells and the proportions were assigned to one of five categories: $0,<5 \% ; 1,5-25 \% ; 2,26-$ $50 \% ; 3,51-75 \%$; and $4,>75 \%$. The percentage of positivity of the tumor cells and the staining intensity were then multiplied to generate the immunoreactivity score for each of the tumor specimens. A mean immunoreactivity score was calculated from the three samples per patient. The expression pattern of each marker in the complete tumor samples was determined independently by two investigators ( $\mathrm{MB}$ and $\mathrm{BME}$ ). An attempt to avoid observer bias was made by repeating the evaluation of protein expression at two different time points and without knowledge of patients' clinical data.

\section{Cell Culture}

The Merkel cell carcinoma cell lines MCC13 and MCC1412 were grown to a confluent monolayer in $175 \mathrm{~cm}^{2}$ polystyrene flasks with ventilation caps (Sarstedt) in RPMI 1640 medium containing 10\% fetal calf serum and $100 \mathrm{U} / \mathrm{ml}$ penicillin and $100 \mu \mathrm{g} /$ $\mathrm{ml}$ streptomycin (all reagents from Life Technologies, Paisley, Scotland) at $37^{\circ} \mathrm{C}$ in a humidified atmosphere of $5 \% \mathrm{CO}_{2}$ until confluence. The tongue carcinoma cell lines SCC9 and SCC25 were used as reference cell lines and for the establishment of the GeneRacer technology because they were more easy to handle and readily obtainable from the American Type Culture Collection. Cells were counted in a Casy1 cell counter (Schärfe Systems, Reutlingen, Germany).

\section{RNA Isolation}

RNA was isolated from approximately $1 \times 10^{8}$ cells grown in cell culture using the RNeasy Midi Kit (Qiagen, Hilden, Germany) and the total RNA isolation protocol for animal cells according to the manufacturer's recommendations with minor modifications. ${ }^{25}$ In brief the cells were harvested by transferring $4 \mathrm{ml}$ of ice-cold buffer RLT containing $0.143 \mathrm{M} \beta$-mercaptoethanol evenly onto the monolayer. The cells were collected by quickly scraping the surface of the vessel with a rubber policeman, pipetted into a $50 \mathrm{ml}$ polypropylene tube (Sarsted), and stored on ice. The cell lysate was homogenized by centrifugation (13 000 g/2 min; Eppendorf 5417 R) through Qiashredder columns (Qiagen). The flow through was collected in $15 \mathrm{ml}$ polypropylene tubes, mixed with $4 \mathrm{ml}$ of ice-cold $70 \%$ ethanol (SigmaAldrich), transferred to an RNeasy column, and centrifuged. DNA was digested on column after washing the anion exchange resin with $2 \mathrm{ml}$ of buffer RW1 by the addition of $160 \mu \mathrm{l}$ of a DNase I incubation mix (approximately 55 Kunitz units resuspended in buffer RDD; Qiagen). After incubation for $15 \mathrm{~min}$ at room temperature the column was washed with $2 \mathrm{ml}$ buffer RW1. Buffer RPE was applied onto the RNeasy column twice ( $2.5 \mathrm{ml}$ each). The column was dried by a third centrifugation step using a new collection tube.

RNA was eluted twice with RNase-free water (200 and $150 \mu \mathrm{l}$, each), aliquoted, and immediately stored on $-70^{\circ} \mathrm{C}$. All centrifugation steps were performed at $5000 \mathrm{~g}$ for $5 \mathrm{~min}$ at room temperature in a Hettich Rotanta 46 device unless otherwise stated. The quality of the RNA isolate was assessed by calculating the absorption quotient at 260 and $280 \mathrm{~nm}$. The integrity of the RNA was checked on a native $1 \%$ agarose gel after staining with ethidium bromide. 


\section{Reverse Transcription}

RNA was reverse transcribed using the RevertAid H Minus First Strand cDNA synthesis kit (Fermentas, St Leon-Rot, Germany) according to the manufacturer's protocol. ${ }^{26}$ All steps were performed quickly on ice. Briefly, $10 \mu \mathrm{l}$ of total RNA $(0.5 \mu \mathrm{g} / \mu \mathrm{l})$ was transferred into a $0.2 \mathrm{ml}$ PCR clean reaction tube (Eppendorf). $1 \mu \mathrm{l}$ of the oligo $\mathrm{dT}_{18}$ primer solution $(0.5 \mu \mathrm{g} / \mu \mathrm{l})$ and $1 \mu \mathrm{l}$ RNase-free water were added, mixed, and spun down. The RNA solution was denatured for $5 \mathrm{~min}$ at $70^{\circ} \mathrm{C}$ on a thermocycler (Hybaid PCR Express HBPX110, Heidelberg, Germany) and immediately chilled on ice. The RT master mix was prepared by adding $4 \mu \mathrm{l}$ of $5 \times$ reaction buffer, $1 \mu$ l Ribolock ribonuclease inhibitor $(20 \mathrm{U})$, and $2 \mu \mathrm{l}$ of a $10 \mathrm{mM}$ dNTP mix per reaction. The solution was gently mixed by pipetting and spun down. The RT master mix $(7 \mu \mathrm{l})$ was transferred to $12 \mu \mathrm{l}$ denatured RNA solution and incubated at $37^{\circ} \mathrm{C}$ for $5 \mathrm{~min}$ on the thermocycler. Then $1 \mu \mathrm{l}$ RevertAid H Minus M-MuLV RT (200 U/ $\mu \mathrm{l})$ was added and the assay was incubated for $60 \mathrm{~min}$ at $42^{\circ} \mathrm{C}$. The reaction was stopped by a heating step to $70^{\circ} \mathrm{C}$ for $10 \mathrm{~min}$. The cDNA was aliquoted and stored at $-20^{\circ} \mathrm{C}$.

\section{Quantitative Real-Time PCR}

Quantitative real-time PCR was performed on the LightCycler 1.5 system using glass capillaries and the Quantitect SYBR Green PCR mastermix (Qiagen). The PCR assay contained $5 \mu \mathrm{l}$ of the $2 \times$ Quantitect mastermix, $0.3 \mu \mathrm{l}$ of the left and right primer achieving a final concentration of $0.3 \mu \mathrm{M}$, each, and $2.4 \mu \mathrm{l}$ RNase-free water. This mixed solution $(8 \mu \mathrm{l})$ was pipetted into a glass capillary followed by the addition of $2 \mu \mathrm{l}$ of the cDNA containing the target sample dilution. After a short centrifugation (3000 r.p.m./30 s) the capillaries were transferred into the LightCycler. The amplification conditions were as follows: an initial denaturation at $95^{\circ} \mathrm{C}$ for $15 \mathrm{~min}$ was followed by 45 cycles of $94^{\circ} \mathrm{C} / 15 \mathrm{~s}$, an annealing step at $60^{\circ} \mathrm{C}$ for $20 \mathrm{~s}$, and an elongation for $10 \mathrm{~s}$ at $72{ }^{\circ} \mathrm{C}$. The target was identified by a melting curve analysis using the continuous mode and a temperature profile from 70 to $95^{\circ} \mathrm{C}$ in increments of $0.1^{\circ} \mathrm{C}$. The melting curves were verified by agarose gel electrophoresis. The relative abundance of long (mRNA3) and short (mRNA1) CD9 mRNA in MCC cell lines was established with absolute quantification using an external standard curve. A CD9 5F74/CD9 gr18 PCR amplicon, which was excised from an agarose gel and purified with the Wizard SV Gel Clean-Up System (Promega, Leiden, the Netherlands) served as external standard. The standard curve was created by semilogarithmic dilutions of the spectrophotometrically quantified amplicon starting with 10000 and closing with 80 copies per PCR assay. Each dilution was analyzed in triplicates. Dilutions of the RT assays
$(1: 25,1: 125$, and $1: 625)$ were quantified similarly in the same PCR run. Quantification was performed using the second-derivative maximum method supplied with the LightCycler 3.5.3 software.

\section{CD9 Specific Primers $\left(5^{\prime} \rightarrow 3^{\prime}\right)$}

The primer sequences are denoted in $5^{\prime}-3^{\prime}$ orientation. CD9 5F73, 5'-CAGGTCCCGCCAGTCCCAGC-3' (left primer; short 5' UTR); CD9 5F74, 5'-CGCACCG CAGCGGGTCGC-3' (left primer; long $5^{\prime}$ UTR); CD9 gr18, 5'-CCGGCAAGCCAGAAGATGAAGTTA A-3' (right primer; CD9 Exon 1/Exon 2 overlapping region).

Primers were constructed with Vector NTI 7.1 software suite (Informax/Invitrogen, Carlsbad, CA, USA) using the GenBank entry NM_001769 and the NCBI reference sequence NT_009759.15 as target sequences.

\section{Characterization of the CD9 mRNA $5^{\prime}$ UTR}

The transcription initiation site of the CD9 mRNA was characterized using the GeneRacer kit (Invitrogen) and the protocol recommended by the manufacturer. $^{27}$ The application of the GeneRacer methodology was based upon rapid amplification of cDNA ends and guaranteed full-length $5^{\prime}$ ends of RNA transcripts by capturing only $5^{\prime}$ capped mRNAs avoiding truncated RNAs or other artifacts. The agarose gel extracted amplicons (Wizard SV Gel Clean-Up System; Promega) were cloned into the pCR2.1 vector using the TOPO TA cloning kit from Invitrogen. Plasmid DNA was isolated from 20 randomly chosen bacterial clones with the Qiaprep Spin Miniprep kit (Qiagen). The inserts were sequenced at VBC Genomics (Vienna, Austria) using the dideoxy chain termination technology.

\section{RNA Secondary Structure Calculation}

The secondary structure of the CD9 $5^{\prime}$ UTR mRNA was calculated with the software RNAshapes and displayed with Pseudoviewer2.5. The results were validated by reanalysis with RNAstructure 4.2 applying default values based on the Zuker algorithm for free energy minimization using the nearest neighbor parameters of Turner and coworkers. ${ }^{28-30}$

\section{Statistical Analysis}

The overall survival was defined as the period from the patient's first visit to the outpatient department until the end of the study (1 May 2009). The diseasefree interval was defined as the period from the patient's first visit to the final date of the study, or the period from the patient's first visit to the outpatient department to the date of recurrent disease being diagnosed. The overall survival and 
disease-free interval curves of all patients were estimated by the univariate Kaplan-Meier method and the log-rank test. For multivariate testing, we used Cox regression analysis with forward selection. A value of $P<0.05$ was considered statistically significant. The Statistical Package for the Social Sciences Software, Version 15.0 for Windows (SPSS UK, Surrey, UK), was used for analysis.

\section{Results}

\section{Clinical Data}

A total of 28 tissue specimens from 25 patients (13 men, 12 women; aged 57-96 years; median 77 years) with diagnosed Merkel cell carcinoma were analyzed for protein expression patterns of CD9, CD37, CD63, and CD151. Fifteen tumors (53\%) were located in the head and neck region and eight $(29 \%)$ on the extremities. One primary tumor $(4 \%)$ and three metastasis specimens $(11 \%)$ could not be localized. Twenty patients $(80 \%)$ presented with early disease (Stage I), three with Stage II (12\%), and two with Stage III $(8 \%)$. At the completion of the study, seven $(28 \%)$ were alive without disease and one $(4 \%)$ was alive with disease. Eleven died of the disease $(44 \%)$ and six died of other causes $(24 \%)$. Details on clinical data are provided in Table 1.

\section{Microscopy}

Two distinct types of Merkel cell carcinomas could be distinguished as already described by Sur et al. ${ }^{31}$ Nine samples showed morphology similar to classical small cell carcinoma. In 18 samples the carcinoma cells were significantly bigger (larger than 3 lymphocytes) and showed high mitotic activity and multiple nucleoli. In five samples, both morphologies were present.

\section{Immunohistochemistry}

A typical immunohistochemical staining of the tetraspanins CD9, CD37, CD63, and CD151 in a tissue array of Merkel cell carcinoma is depicted in Figure 1. A strong positive staining signal was obtained in two cases for CD9 (specimen 13/12) and CD151 (specimen 2/2), both from primary tumors. Concerning CD9 expression, $15 \%$ of the samples produced a weak, $12 \%$ a moderate, and $4 \%$ a strong signal. No CD9 signal was obtained from $69 \%$ of all samples where data could be retrieved. CD37 was weakly positive with $60 \%$ of the samples, but only $8 \%$ showed a moderate signal and no sample was strongly positive. $32 \%$ of the samples were negative for CD37. CD63 was weakly positive in $50 \%$ of the tested samples and $27 \%$ showed a moderate staining pattern. No sample was strongly positive for CD63, but $23 \%$ were negative. CD151 displayed a weak signal in $36 \%$. Of the samples,
$21 \%$ were moderately stained by CD151-specific antibodies. No CD151\% specific signal could be retrieved from $39 \%$ of the samples.

Follow-up samples were collected from three patients. Three specimens were in-transit skin metastases (11/11, 12/11, and 16/15). Two specimens were from lymph nodes (23/21 and 24/21). Specimen 17/15 from a primary tumor was CD9 and CD37 negative, but showed signals for CD63 and CD151. Specimen 16/15 was isolated 1 year later from an intransit metastasis and had lost CD63 but gained CD37 (Figure 2). The expression patterns of CD9, CD37, CD63, and CD151 including tumor type and tumor stage of the analyzed tissue specimens are displayed in Figure 2. A quantitative evaluation of the immunohistochemistry results is compiled in Table 3.

CD9 was significantly more prevalent on primary tumors $(42 \%)$ compared to subcutaneous metastatic in-transit and lymph node metastases $(21 \%)$. The expression patterns of CD37, CD63, and CD151 showed no obvious difference between primary and metastatic tumor specimens. The establishment of a correlation between tumor stage and tetraspanin expression patterns was not feasible (Figure 2 and Table 3).

\section{Prognostic Evaluation of the Tissue Expression Data}

After multivariate analysis, CD9 overexpression significantly correlated to prolonged overall survival of the patient $(P=0.03)$ and the disease-free interval $(P=0.017)$. Univariate analysis showed that diseasefree interval correlates to $\operatorname{CD63}(P=0.058)$ and overall survival to CD151 overexpression $(P=0.043)$ (Table 3).

\section{CD9 5' UTR mRNA}

GeneRacer analysis

GeneRacer characterization of the $5^{\prime}$ UTR of the CD9 mRNA from Merkel cell carcinomas revealed the presence of two major mRNA species: long CD9 mRNAs with $5^{\prime}$ UTRs of 183 nucleotides (nts) and shorter mRNAs with 5' UTRs of 102 nts (Figure 3).

\section{Computational analysis}

Computational analysis of the short 102 nts CD9 5' UTR predicted two major stem-loop structures and 17 GC base pairs preceding the starting point for translation. The structure showed a minimum free energy of $-23.09 \mathrm{kcal} / \mathrm{mol}$ and a shape probability of $P=0.016$ (Figure 4). In contrast, the predicted secondary structure of the 183 nts $5^{\prime}$ UTR composed of 4 major stem-loop elements and 36 GC base pairs preceding the translation initiation site. The folding pattern leads to a calculated minimum free energy of $-58.6 \mathrm{kcal} / \mathrm{mol}(P=0.0013)$ (Figure 4). Secondary structure analysis of CD9 mRNA $5^{\prime}$ UTRs of 80 and $172 \mathrm{nts}$ (proposed by Rubinstein et $a \mathrm{l}^{17}$ ) revealed two major stem-loop structures for the $80 \mathrm{nts}$ fragment 

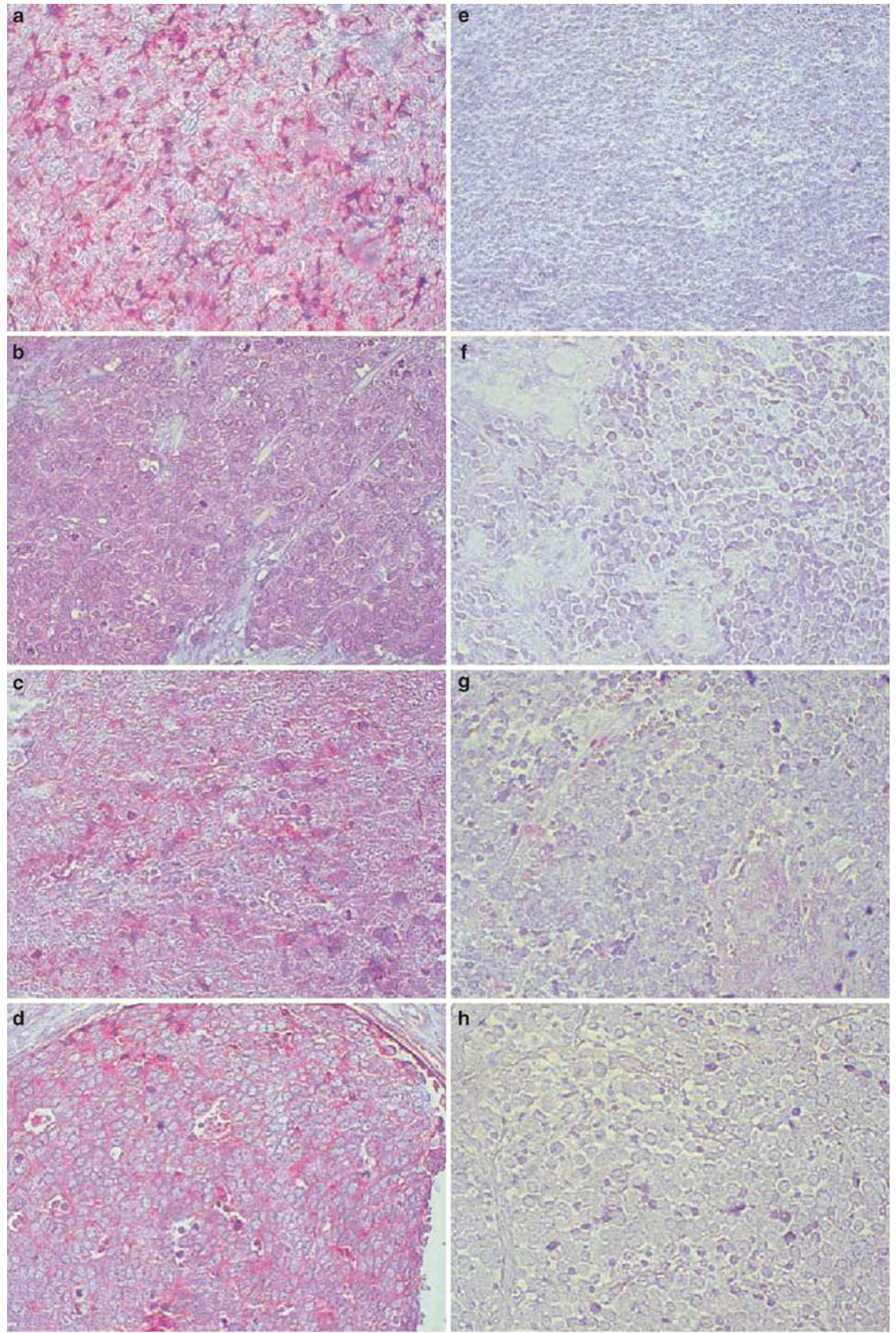

Figure 1 The immunostaining of tetraspanin molecules in a tissue microarray of Merkel cell carcinoma. Positive expression of CD9, CD37, CD63, and CD151 is shown on panels a-d and negative staining on panels $\mathbf{e}-\mathbf{h}$. CD9 (a) and CD151 (d) show the typical membranous staining pattern whereas CD37 and CD63 were expressed in the cytoplasm. All photomicrographs were taken at a magnification $\times 200$. 


\begin{tabular}{|c|c|c|c|c|c|c|}
\hline & Type of tumor & Tumor stage & CD9 & CD37 & CD63 & CD151 \\
\hline $1 / 1$ & primary & I & & & & \\
\hline $2 / 2$ & primary & 1 & & & & \\
\hline $3 / 3$ & primary & 1 & & & & \\
\hline $4 / 4$ & metastasis & III & & & & \\
\hline $5 / 5$ & primary & 1 & & & & \\
\hline $6 / 6$ & primary & 1 & & & & \\
\hline $7 / 7$ & metastasis & 1 & & & & \\
\hline $8 / 8$ & metastasis & 1 & & & & \\
\hline $9 / 9$ & metastasis & II & & & & \\
\hline $10 / 10$ & metastasis & 1 & & & & \\
\hline $11 / 11$ & metastasis & 1 & & & & \\
\hline $12 / 11$ & metastasis & NA & & & & \\
\hline $13 / 12$ & primary & 1 & & & & \\
\hline $14 / 13$ & primary & 1 & & & & \\
\hline $15 / 14$ & primary & 1 & & & & \\
\hline $16 / 15$ & metastasis & NA & & & & \\
\hline $17 / 15$ & primary & 1 & & & & \\
\hline $18 / 16$ & primary & II & & & & \\
\hline $19 / 17$ & metastasis & III & & & & \\
\hline $20 / 18$ & primary & 1 & & & & \\
\hline $21 / 19$ & primary & 1 & & & & \\
\hline $22 / 20$ & metastasis & 1 & & & & \\
\hline $23 / 21$ & metastasis & NA & & & & \\
\hline $24 / 21$ & metastasis & 1 & & & & \\
\hline $25 / 22$ & metastasis & 1 & & & & \\
\hline $26 / 23$ & metastasis & 1 & & & & \\
\hline $27 / 24$ & metastasis & 1 & & & & \\
\hline $28 / 25$ & primary & II & & & & \\
\hline
\end{tabular}

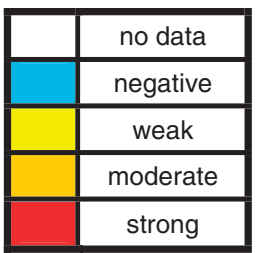

Figure 2 Twenty-eight Merkel cell carcinoma specimens from 25 patients were immunohistochemically screened for tissue expression of the tetraspanins CD9, CD37, CD63, and CD151. The presented overall immunoreactivity score (negative, weak, moderate, strong) was calculated by multiplication of the staining intensity (1, weak; 2 , moderate; or 3 , strong) with the percentage of stained cells $(0$, $<5 \%$; 1 , $5-25 \% ; 2,26-50 \% ; 3,51-75 \%$; and 4, > 75\%) in the specimen. From 112 tests, 105 yielded interpretable results. Of all results, 76\% were negative or showed only a weak immunoreactivity, $16 \%$ were moderately reactive. Two specimens showed a strong reaction. NA $=$ no data available.

with 13 GC pairs preceding the translation initiation site and a minimum free energy of $-16.7 \mathrm{kcal} / \mathrm{mol}$ $(P=0.005)$. The most probable secondary structure of the 172 nts long $5^{\prime}$ UTR produced 5 stem-loops with 36 GC base pairs (delta $\mathrm{G}=-52.4 \mathrm{kcal} / \mathrm{mol}$; $P=0.0018$ ) (Figure 4). Both long CD9 $5^{\prime}$ UTRs of 183 and $172 \mathrm{nts}$, respectively, contain a short openreading frame coding for 9 amino acids (Figure 3). In combination with the conformational data and the free minimum energy constraints the structure of these $5^{\prime}$ UTRs are prone to inhibit ribosomal scanning, assembly, and CD9 mRNA translation.

\section{Quantitative analysis}

Quantitative analysis of long and short 5' UTRs with real-time RT-PCR revealed a substantially lower overall transcription of CD9 mRNA in Merkel cell carcinoma cell lines $\left(1 \times 10^{6}\right.$ copies/ $\mu \mathrm{g}$ total RNA $)$ compared to squamous cell carcinoma cell lines $\left(\right.$ SCC9 $=3.8 \times 10^{6} ;$ SCC25 $\left.=6.6 \times 10^{6}\right)($ Table 4$)$. The presented absolute CD9 mRNA copy numbers per $\mu \mathrm{g}$ of total isolated RNA were mean values of 13 PCR runs from 4 independent experiments. A quantitative shift from short (=RNA1) to long (= RNA3) mRNAs obviously correlating with a loss of CD9 on the cell surface and an increase of the metastatic potential of the analyzed cells were substantiated by RNA3/RNA1 ratios as follows: $\mathrm{MCC} 13=0.12$; MCC1412 $=0.09$; SCC9 $=0.05$; SCC25 $=0.03$ (Table 4).

\section{Discussion}

We could establish a correlation between CD9 overexpression and a longer survival time and disease-free interval for patients suffering from 
Table 3 Quantitative evaluation of immunohistochemistry data and clinical outcome of tetraspanin expression in Merkel cell carcinoma tissue

\begin{tabular}{|c|c|c|c|c|c|c|c|c|c|c|}
\hline & \multirow[t]{2}{*}{ Tumor type } & \multicolumn{2}{|c|}{$C D 9$} & \multicolumn{2}{|c|}{ CD37 } & \multicolumn{2}{|c|}{ CD63 } & \multicolumn{2}{|c|}{$C D 151$} & \multirow[t]{2}{*}{ Staining } \\
\hline & & No. & $\%$ & No. & $\%$ & No. & $\%$ & No. & $\%$ & \\
\hline & Primary & 7 & 58 & 4 & 33 & 2 & 16 & 4 & 31 & Negative \\
\hline & \multirow[t]{2}{*}{ Metastasis } & 11 & 79 & 4 & 31 & 4 & 29 & 7 & 47 & \\
\hline & & 18 & 69 & 8 & 32 & 6 & 23 & 11 & 39 & Sum negative \\
\hline & \multirow{5}{*}{$\begin{array}{l}\text { Primary } \\
\text { Metastasis }\end{array}$} & 5 & 42 & 8 & 67 & 10 & 85 & 9 & 69 & Positive \\
\hline & & 3 & 21 & 9 & 69 & 10 & 71 & 8 & 53 & \\
\hline & & 8 & 31 & 17 & 68 & 20 & 77 & 17 & 61 & Sum positive \\
\hline & & 2 & & 3 & & 2 & & 0 & & No data \\
\hline & & 28 & & 28 & & 28 & & 28 & & $\begin{array}{l}\text { Total number } \\
\text { of specimens }\end{array}$ \\
\hline Parameter & Procedure & & & & & & & & & \\
\hline \multirow[t]{2}{*}{ Survival } & Kaplan-Meier & \multicolumn{2}{|c|}{0.16} & \multicolumn{2}{|c|}{ Not significant } & \multicolumn{2}{|c|}{0.07} & \multicolumn{2}{|c|}{0.043} & \\
\hline & Cox regression & \multicolumn{2}{|c|}{0.03} & \multicolumn{2}{|c|}{ Not significant } & \multicolumn{2}{|c|}{ Not significant } & \multicolumn{2}{|c|}{0.15} & \\
\hline \multirow[t]{2}{*}{ Disease-free interval } & Kaplan-Meier & \multirow{2}{*}{\multicolumn{2}{|c|}{$\begin{array}{l}0.074 \\
0.017\end{array}$}} & \multirow{2}{*}{\multicolumn{2}{|c|}{$\begin{array}{l}\text { Not significant } \\
\text { Not significant }\end{array}$}} & \multirow{2}{*}{\multicolumn{2}{|c|}{$\begin{array}{c}0.058 \\
\text { Not significant }\end{array}$}} & \multirow{2}{*}{\multicolumn{2}{|c|}{ Not significant }} & \\
\hline & Cox regression & & & & & & & & & \\
\hline
\end{tabular}
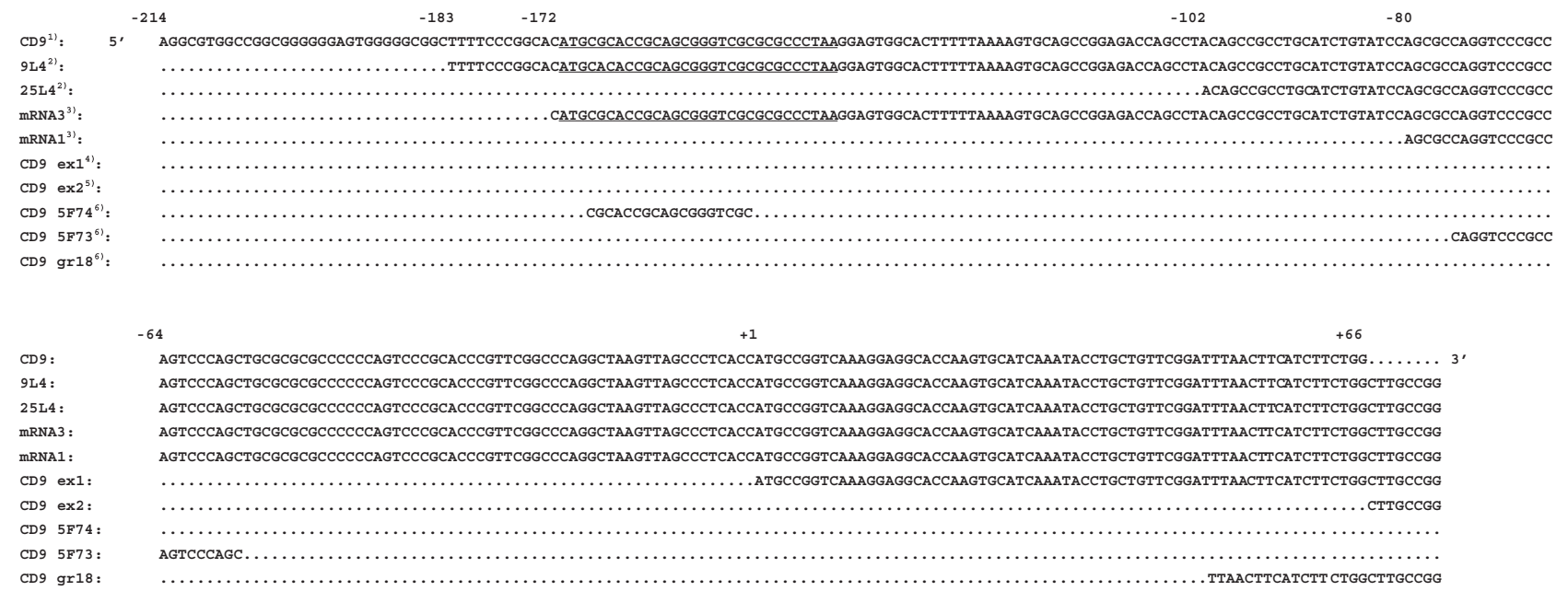

Figure 3 CD9 5' UTR mRNA sequences (9L4, 25L4) obtained from Merkel cell carcinoma cell lines by the GeneRacer technology were aligned with the CD9 genomic sequence and mRNA sequences (mRNA3, mRNA1) found by Rubinstein et al. ${ }^{17}$ For comparison the start of Exon 1 and Exon 2 as well as the positions of the applied primers are denoted. The short open-reading frame in the long $5^{\prime}$ UTRs is underlined. ${ }^{1}$ Genomic CD9 DNA sequence (NCBI reference sequence: NT_009759.15): position (-214) - ( + 74) relative to the translation initiation AUG start codon. ${ }^{2}$ Maximum and minimum length CD9 mRNA fragments (obtained from 20 GeneRacer clones). ${ }^{3} \mathrm{CD} 9$ mRNA transcription initiation sites according to Rubinstein et al. ${ }^{17}{ }^{4} \mathrm{CD} 9 \mathrm{mRNA}$ sequence starting at the translation initiation site within Exon 1. ${ }^{5} 5^{\prime}$ sequence fragment of CD9 Exon 2. ${ }^{6}$ PCR primers for real-time PCR and GeneRacer assays.

Merkel cell carcinoma by immunohistochemical staining of the respective tissue samples. This observation corresponds with previous reports showing that the level of CD9 expression is predictive for a disease-free survival in patients with squamous cell carcinoma of the head and neck $^{32,33}$ and that CD9 is a good prognosis factor in breast, ${ }^{34}$ lung, ${ }^{35}$ colon, ${ }^{36}$ and pancreas cancer. ${ }^{37}$ In all of these malignancies, a downregulation of CD9 leads to tumor progression and to metastasis. We can extend these findings to Merkel cell carcinoma because we observed significantly more primary tumor tissue samples displaying CD9 protein expression than were CD9 negative. Loss of CD9 expression was substantially more prevalent in subcutaneous Merkel cell carcinoma in-transit and lymph node metastases compared to primary tumor tissue samples. These data are in good correlation with common knowledge because CD9 is known to be a potent suppressor of tumor progression by inhibition of integrin-mediated motility. ${ }^{9}$

We observed a clear correlation between CD63 expression in Merkel cell carcinomas and the disease-free interval of the patients. This observation is supported by the discovery that CD63 is strongly expressed in early stages of melanoma and would be downregulated only at later stages when the tumor starts to progress. In the reported case, 

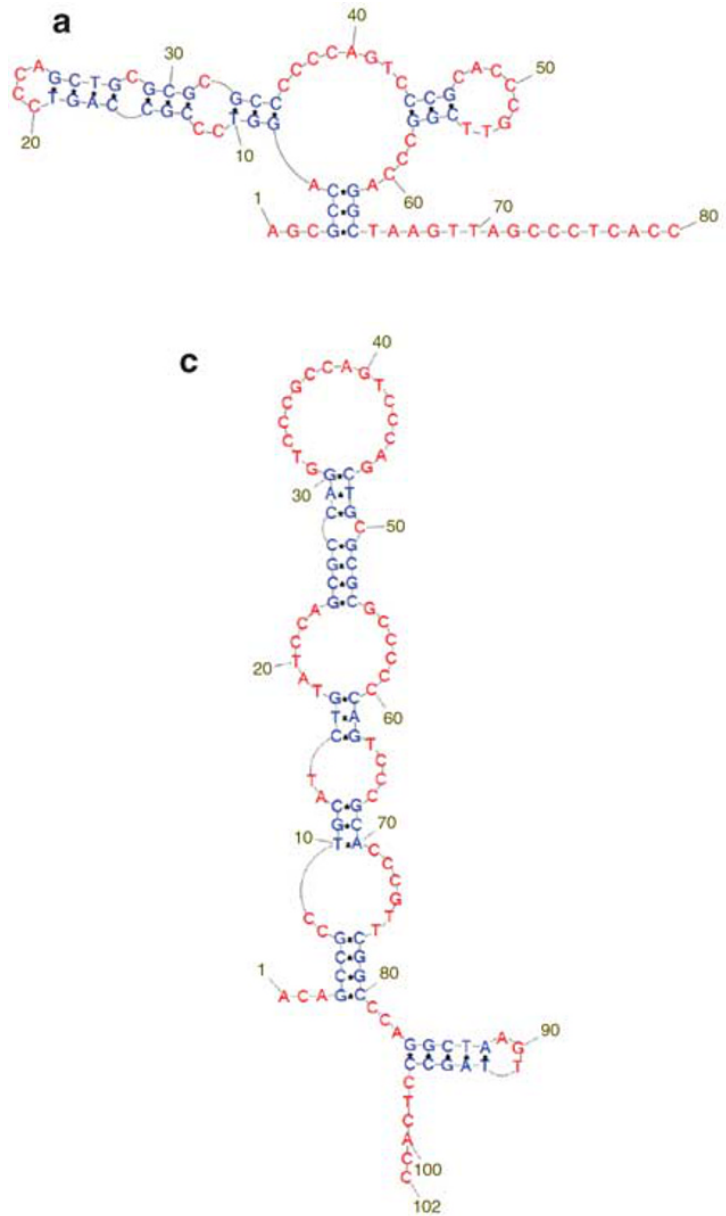

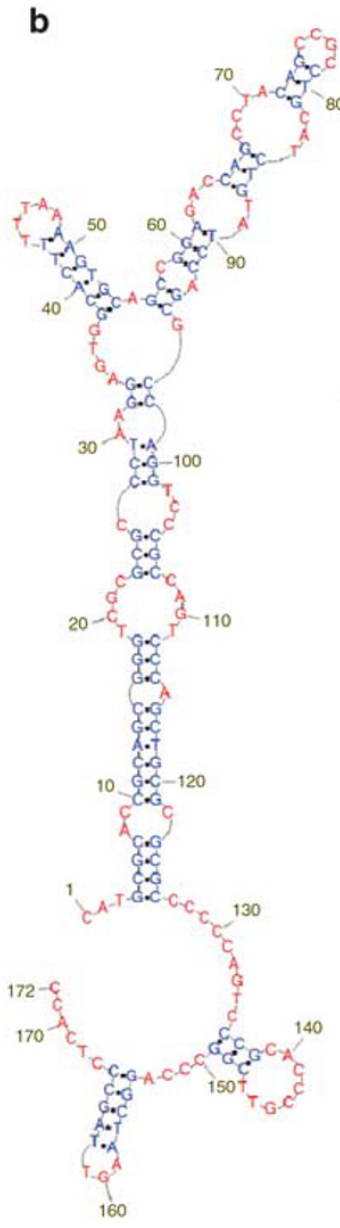

d
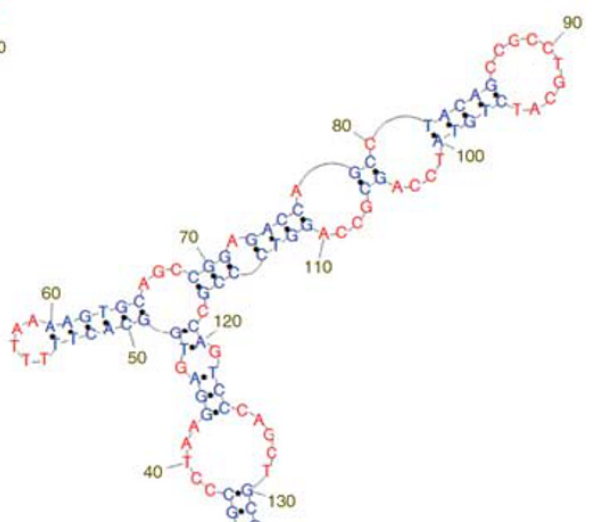

Figure 4 The calculated RNA secondary structures of CD9 5' UTRs 25L4 and 9L4 found in Merkel cell carcinoma cell lines are depicted (c and d) and compared to CD9 $5^{\prime}$ untranslated region (UTRs) mRNA1 and mRNA3 from leukemia cell lines (a and b). A short $5^{\prime}$ UTRs with a low complexity and a low free energy folding pattern (mRNA1: $\Delta \mathrm{G}=-16.7 \mathrm{kcal} / \mathrm{mol} ; 25 \mathrm{~L} 4: \Delta \mathrm{G}=-23.09 \mathrm{kcal} / \mathrm{mol}$ ) supports optimal ribosomal scanning and mRNA translation. Complex series of stem-loops requiring a high amount of energy to be resolved (mRNA3: $\Delta \mathrm{G}=-52.4 \mathrm{kcal} / \mathrm{mol} ; 25 \mathrm{~L} 4: \Delta \mathrm{G}=-58.6 \mathrm{kcal} / \mathrm{mol}$ ) in combination with the internal open-reading frame are supposed to block CD9 mRNA translation. Both long and short $5^{\prime}$ UTRs are present concomitantly in Merkel cell carcinomas. Tumor progression is accompanied by a shift to the longer CD9 mRNA.

CD63 expression analysis provided a good prognosis tool for evaluating the status of melanoma. ${ }^{13}$

We could show that the level of expression of CD151 in Merkel cell carcinoma correlates inversely to the survival of the patient. This is in line with reports that identified CD151 as tumor progression marker. CD151 inhibits tumor cell intravasation ${ }^{38}$ and promotes cell migration by regulation of integrin movements. ${ }^{39}$ Sauer et $a 7^{7}$ reported a coupling of the expression of CD9, CD63, and CD151 in breast cancer cells and a reduction of expression below certain thresholds were predictive at least for in vitro invasiveness. We could not observe a coupled expression of tetraspanins in Merkel cell carcinoma tissue samples: the evaluation of marker combinations was diagnostically not more conclusive concerning survival or disease-free interval than analysis of a single tetraspanin. The analysis of CD37 tissue expression patterns was not of prognostic relevance.
We discovered the coincident presence of two CD9 mRNA species in Merkel cell carcinomas, which differed only in the length of their $5^{\prime}$ UTRs. In silico analysis of the long $183 \mathrm{nts} 5^{\prime}$ UTR revealed a high GC content, a complex secondary structure comprising of stable stem-loops, and a short openreading frame coding for 9 amino acids. These data are characteristic for $5^{\prime}$ UTRs that inhibit ribosomal translation. ${ }^{21}$ The short $5^{\prime}$ UTR of 102 nts is predicted to produce a folding pattern, which allows an optimal translation of the CD9 mRNA. ${ }^{21}$ Quantitative analysis of each short and long CD9 mRNA species revealed not only an overall reduction of CD9 mRNAs in metastasizing cells but also a subtle shift from shorter to longer $5^{\prime}$ UTRs. This implies the conclusion that not only a reduction of the absolute quantity of CD9 mRNA can reduce the amount of the produced CD9 protein: A shift from shorter to longer $5^{\prime}$ UTRs had a similar effect and could reduce protein assembly due to blocking of protein 
Table 4 CD9 mRNA expression in Merkel cell carcinoma and squamous cell carcinoma cell lines

\begin{tabular}{|c|c|c|c|c|}
\hline & \multicolumn{3}{|c|}{ 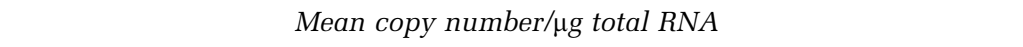 } & \multirow{2}{*}{$\begin{array}{c}\text { Ratio } \\
\text { RNA3/RNA1 }\end{array}$} \\
\hline & $\begin{array}{c}R N A 1 \\
\text { (short } 5^{\prime} \text { UTR) }\end{array}$ & $\begin{array}{c}R N A 3 \\
\text { (long } 5^{\prime} \text { UTR) }\end{array}$ & $\begin{array}{c}\text { CD9 mRNA } \\
(\text { RNA1 + RNA3) }\end{array}$ & \\
\hline MCC13 & 922181 & 103097 & 1025278 & 0.12 \\
\hline MCC1412 & 935633 & 77742 & 1013075 & 0.09 \\
\hline SCC9 & 3674677 & 176365 & 3851042 & 0.05 \\
\hline SCC25 & 6408292 & 197542 & 6605835 & 0.03 \\
\hline
\end{tabular}

translation by inhibiting eukaryotic ribosomal assembly. ${ }^{40,41}$ This quantitative shift allows a subtle fine-tuning of the expression of CD9 by gradually changing the ratio of long and short mRNAs. A regulation of protein expression by structured $5^{\prime}$ UTRs has been described for several prominent housekeeping and proto-oncogenes, such as the transforming growth factor $\beta$-family, brca1, c-mos, bcl-2, and mdm2. ${ }^{21,41}$ Complex $5^{\prime}$ UTR folding patterns may also offer the opportunity for finetuning of gene expression on the posttranscriptional level. ${ }^{41}$ Variable CD9 mRNA species ratios may be also of certain relevance concerning the control of CD9 expression in normal tissue because this receptor is involved in a multitude of cellular interactions, such as egg-sperm fusion, ${ }^{16}$ activating platelets, ${ }^{17}$ suppressing motility and promoting adherence to the surrounding matrix by interactions with integrins, signaling proteins, and immunoglobulin superfamily members. ${ }^{9}$ Regulation of CD9 gene expression has been attributed to the acquisition and action of specific transcription factors, ${ }^{17}$ CpG methylation of promoter regions ${ }^{42}$ or to histone modifications ${ }^{43}$ which led to CD9 silencing at least in myeloma cell lines. But-to our knowledge-regulation of CD9 gene expression relying on posttranscriptional effects due to $5^{\prime}$ UTRs with complex secondary structures has not been in discussion, yet. ${ }^{21}$ Notwithstanding, a gradual change of the ratio of short and long $5^{\prime}$ UTRs containing CD9 mRNAs may provide an additional molecular explanation how Merkel cell carcinomas are gradually transforming from tissue-bound tumor to aggressive metastatic cells.

We could show that the analysis of the expression profiles of CD9, CD63, and CD151 is of prognostic relevance and should help to establish therapy regimens tailored for patients who suffer from Merkel cell carcinoma. The proposed model of posttranscriptional regulation of CD9 gene expression may help to understand how CD9 is able to facilitate a multitude of diverse cellular functions in normal tissues and malignant diseases.

\section{Acknowledgement}

We thank Helga Martinek for maintaining the cell culture.

\section{Disclosure/conflict of interests}

The authors declare no conflict of interest.

\section{References}

1 Miller RW, Rabkin CS. Merkel cell carcinoma and melanoma: etiological similarities and differences. Cancer Epidemiol Biomarkers Prev 1999;8:153-158.

2 Becker JC, Schrama D, Houben R. Merkel cell carcinoma. Cell Mol Life Sci 2009;66:1-8.

3 Lawenda BD, Arnold MG, Tokarz VA, et al. Analysis of radiation therapy for the control of Merkel cell carcinoma of the head and neck based on 36 cases and a literature review. Ear Nose Throat J 2008;87: 634-643.

4 Becker JC, Kauczok CS, Ugurel S, et al. Merkel cell carcinoma: molecular pathogenesis, clinical features and therapy. J Dtsch Dermatol Ges 2008;6:709-719.

5 Gillenwater AM, Hessel AC, Morrison WH, et al. Merkel cell carcinoma of the head and neck: effect of surgical excision and radiation on recurrence and survival. Arch Otolaryngol Head Neck Surg 2001; 127:149-154.

6 Horejsi V, Vlcek C. Novel structurally distinct family of leucocyte surface glycoproteins including CD9, CD37, CD53 and CD63. FEBS Lett 1991;288:1-4.

7 Sauer G, Kurzeder C, Grundmann R, et al. Expression of tetraspanin adaptor proteins below defined threshold values is associated with in vitro invasiveness of mammary carcinoma cells. Oncol Rep 2003;10: 405-410.

8 Tokuhara T, Hasegawa H, Hattori N, et al. Clinical significance of CD151 gene expression in non-small cell lung cancer. Clin Cancer Res 2001;7:4109-4114.

9 Zoller M. Tetraspanins: push and pull in suppressing and promoting metastasis. Nat Rev Cancer 2009; 9:40-55.

10 Boucheix C, Rubinstein E. Tetraspanins. Cell Mol Life Sci 2001;58:1189-1205.

11 Okochi H, Kato M, Nashiro K, et al. Expression of tetraspans transmembrane family (CD9, CD37, CD53, CD63, CD81 and CD82) in normal and neoplastic human keratinocytes: an association of CD9 with alpha 3 beta 1 integrin. Br J Dermatol 1997;137:856-863.

12 Sincock PM, Mayrhofer G, Ashman LK. Localization of the transmembrane 4 superfamily (TM4SF) member PETA-3 (CD151) in normal human tissues: comparison with CD9, CD63, and alpha5beta1 integrin. J Histochem Cytochem 1997;45:515-525.

13 Radford KJ, Mallesch J, Hersey P. Suppression of human melanoma cell growth and metastasis by the 
melanoma-associated antigen CD63 (ME491). Int J Cancer 1995;62:631-635.

14 van Spriel $\mathrm{AB}$, Sofi $\mathrm{M}$, Gartlan $\mathrm{KH}$, et al. The tetraspanin protein CD37 regulates IgA responses and anti-fungal immunity. PLoS Pathog 2009;5:e1000338.

15 Moore K, Cooper SA, Jones DB. Use of the monoclonal antibody WR17, identifying the CD37 gp40-45 Kd antigen complex, in the diagnosis of B-lymphoid malignancy. J Pathol 1987;152:13-21.

16 Rubinstein E, Ziyyat A, Wolf JP, et al. The molecular players of sperm-egg fusion in mammals. Semin Cell Dev Biol 2006;17:254-263.

17 Rubinstein E, Benoit P, Billard M, et al. Organization of the human CD9 gene. Genomics 1993;16:132-138.

18 Frith MC, Valen E, Krogh A, et al. A code for transcription initiation in mammalian genomes. Genome Res 2008;18:1-12.

19 Benoist C, Chambon P. In vivo sequence requirements of the SV40 early promotor region. Nature 1981;290: 304-310.

20 Kozak M. An analysis of $5^{\prime}$-noncoding sequences from 699 vertebrate messenger RNAs. Nucleic Acids Res 1987;15:8125-8148.

21 Willis AE. Translational control of growth factor and proto-oncogene expression. Int J Biochem Cell Biol 1999;31:73-86.

22 Yiengpruksawan A, Coit DG, Thaler HT, et al. Merkel cell carcinoma. Prognosis and management. Arch Surg 1991;126:1514-1519.

23 Kononen J, Bubendorf L, Kallioniemi A, et al. Tissue microarrays for high-throughput molecular profiling of tumor specimens. Nat Med 1998;4:844-847.

24 Sinicrope FA, Ruan SB, Cleary KR, et al. bcl-2 and p53 oncoprotein expression during colorectal tumorigenesis. Cancer Res 1995;55:237-241.

25 Qiagen. RNeasy Midi/Maxi Handbook. June 2001, 2nd edn, 2001. http://www1.qiagen.com/literature/render. aspx?id=162.

26 Fermentas. RevertAid ${ }^{\mathrm{TM}} \mathrm{H}$ Minus First Strand cDNA Synthesis Kit. Revision 05. 2004. http://www.fermentas. com/templates/files/tiny_mce/coa_pdf/coa_k1632.pdf.

27 Invitrogen. GeneRacer(tm) Kit. For full-length, RNA ligase-mediated rapid amplification of $5^{\prime}$ and $3^{\prime} \mathrm{cDNA}$ ends (RLM-RACE). Version L. 8. April 2004. http://tools. invitrogen.com/content/sfs/manuals/generacercdna_man. pdf.

28 Mathews DH. Using an RNA secondary structure partition function to determine confidence in base pairs predicted by free energy minimization. RNA 2004;10:1178-1190.

29 Mathews DH, Disney MD, Childs JL, et al. Incorporating chemical modification constraints into a dynamic programming algorithm for prediction of
RNA secondary structure. Proc Natl Acad Sci USA 2004;101:7287-7292.

30 Mathews DH, Sabina J, Zuker M, et al. Expanded sequence dependence of thermodynamic parameters improves prediction of RNA secondary structure. J Mol Biol 1999;288:911-940.

31 Sur M, AlArdati H, Ross C, et al. TdT expression in Merkel cell carcinoma: potential diagnostic pitfall with blastic hematological malignancies and expanded immunohistochemical analysis. Mod Pathol 2007;20: 1113-1120.

32 Erovic BM, Pammer J, Hollemann D, et al. Motilityrelated protein-1/CD9 expression in head and neck squamous cell carcinoma. Head Neck 2003;25:848-857.

33 Erovic BM, Neuchrist C, Kandutsch S, et al. CD9 expression on lymphatic vessels in head and neck mucosa. Mod Pathol 2003;16:1028-1034.

34 Miyake M, Nakano K, Ieki Y, et al. Motility related protein 1 (MRP-1/CD9) expression: inverse correlation with metastases in breast cancer. Cancer Res 1995;55: 4127-4131.

35 Higashiyama M, Taki T, Ieki Y, et al. Reduced motility related protein-1 (MRP-1/CD9) gene expression as a factor of poor prognosis in non-small cell lung cancer. Cancer Res 1995;55:6040-6044.

36 Mori M, Mimori K, Shiraishi T, et al. Motility related protein 1 (MRP1/CD9) expression in colon cancer. Clin Cancer Res 1998;4:1507-1510.

37 Sho M, Adachi M, Taki T, et al. Transmembrane 4 superfamily as a prognostic factor in pancreatic cancer. Int J Cancer 1998;79:509-516.

38 Zijlstra A, Lewis J, Degryse B, et al. The inhibition of tumor cell intravasation and subsequent metastasis via regulation of in vivo tumor cell motility by the tetraspanin CD151. Cancer Cell 2008;13:221-234.

39 Liu L, He B, Liu WM, et al. Tetraspanin CD151 promotes cell migration by regulating integrin trafficking. J Biol Chem 2007;282:31631-31642.

40 Kozak M. Circumstances and mechanisms of inhibition of translation by secondary structure in eucaryotic mRNAs. Mol Cell Biol 1989;9:5134-5142.

41 van der Velden AW, Thomas AA. The role of the $5^{\prime}$ untranslated region of an mRNA in translation regulation during development. Int J Biochem Cell Biol 1999;31:87-106.

42 Drucker L, Tohami T, Tartakover-Matalon S, et al. Promoter hypermethylation of tetraspanin members contributes to their silencing in myeloma cell lines. Carcinogenesis 2006;27:197-204.

43 De Bruyne E, Bos TJ, Asosingh K, et al. Epigenetic silencing of the tetraspanin CD9 during disease progression in multiple myeloma cells and correlation with survival. Clin Cancer Res 2008;14:2918-2926. 